\title{
The utilization by pigs of methionine from five protein concentrates compared with synthetic methionine
}

\author{
BY JANE LEIBHOLZ \\ Department of Animal Husbandry, University of Sydney, Camden, New South Wales, \\ Sydney 2570, Australia \\ AND A. C. KIRBY \\ Department of Genetics and Biometry, University of Sydney, New South Wales, \\ Sydney 2006, Australia
}

(Received 5 August 1983 - Accepted 1 November 1984)

1. Pigs ( $n 100$ ) between 28 and $56 \mathrm{~d}$ of age were given diets containing one of five protein concentrates $a d$ lib.

2. The utilization of methionine from the protein concentrates was compared with synthetic methionine.

3. Increasing the methionine content of the diets from 1.5 to $2.2 \mathrm{~g} / \mathrm{kg}$ diet increased the weight gains of the pigs from $61 \mathrm{~g} / \mathrm{d}$ to $198-292 \mathrm{~g} / \mathrm{d}$. The feed conversion efficiencies decreased from $2 \cdot 56$ to $1 \cdot 34-1 \cdot 56$.

4. The utilization of methionine from the protein concentrates for weight gain, as compared with synthetic methionine, was meat meal A $0 \cdot 89$, meat meal B 0.97 , soya-bean meal $1 \cdot 02$, cotton-seed meal 0.87 and dried skim milk $1 \cdot 04$.

The (US) National Research Council (1979) summarized the requirement of methionine for pigs of $5-10 \mathrm{~kg}$ live weight as $2.8 \mathrm{~g} / \mathrm{kg}$ diet assuming that the diets contained at least $2.8 \mathrm{~g}$ cystine $/ \mathrm{kg}$. However, there is a wide range of estimates in the literature. Kroening et al. (1965) found the requirement for methionine to be $3.3 \mathrm{~g} / \mathrm{kg}$ dry matter (DM) in the diet while, more recently, estimates of $2.5 \mathrm{~g} / \mathrm{kg} \mathrm{DM}$ were reported by Leibholz (1984) and $4 \cdot 3 \mathrm{~g} / \mathrm{kg} \mathrm{DM}$ by Balugen \& Fetuga (1981). This range of results may be due to different utilization of methionine from various sources of protein.

There is information to suggest that protein concentrates may vary greatly in their availability of lysine (as measured by slope-ratio assay in growing pigs; Batterham et al. 1978 ) but the utilization of other amino acids may not reflect that of lysine (Taverner et al. 1981). The apparent digestibility of methionine to the ileum was measured for five protein concentrates given to young pigs, and the values ranged from 0.74 to 0.86 (Leibholz, 1985). On the other hand, the availability of lysine in these protein concentrates for growing pigs has been evaluated by slope-ratio assay as 0.50-0.88 (Batterham et al. 1979) but no digestibility values were given. In the present experiment, the utilization of methionine in protein concentrates was estimated using a slope comparison with synthetic methionine in pigs $21-49 \mathrm{~d}$ of age, and these studies were compared with earlier estimates of the utilization of methionine made from measurements of apparent digestibility to the ileum (Leibholz, 1985).

\section{EXPERIMENTAL}

\section{Animals and management}

Four groups of twenty-five Large White $\times$ Landrace male pigs were taken from the sows between 17 and $18 \mathrm{~d}$ of age. The pigs were housed in tiered cages in groups of nine to ten for a preliminary period of 2-3 d, during which time they were offered pelleted food.

At $21 \mathrm{~d}$ of age, when the average weight was $5 \cdot 1 \mathrm{~kg}$, pigs were allocated, one per cage, 
Table 1. Composition $(\mathrm{g} / \mathrm{kg})$ of basal diet

\begin{tabular}{lr}
\hline Wheat & 360 \\
Lupins (hulled) & 400 \\
Maize starch & 200 \\
Limestone & 10 \\
Calcium dihydrogen phosphate & 20 \\
Salt & 5 \\
Premix* & 5 \\
\hline
\end{tabular}

* Vitamin and mineral supplement supplying (mg/kg diet): retinol 1.5, cholecalciferol $0 \cdot 025, \alpha$-tocopherol 20 , cyanocobalamin $20 \mu \mathrm{g}$, riboflavin 4 , niacin 20 , pantothenic acid 10 , biotin 01 , iron 100 , copper 10 , manganese 40 , zine 50 ; other additives $(\mathrm{mg} / \mathrm{kg}$ diet): ethoxyquin 100 , oxytetracycline 50 .

to the experimental diets. Diets were offered ad lib., fresh food was offered daily and discards were weighed weekly. Water was provided by nipple drinkers. The pigs were weighed weekly.

The cages were in a controlled-environmental room maintained at $26^{\circ}$. No mortalities occurred during the experiment which was of $28 \mathrm{~d}$ duration.

Faeces were collected on screens above sloping trays, which drained the urine into bottles containing hydrochloric acid $(200 \mathrm{ml}, 5 \mathrm{M})$. The collections were made from $43-49 \mathrm{~d}$ of age.

\section{Diets}

The basal diet (Table 1) contained wheat and lupins (Lupinus augustifolius cv. Unicrop). The lupins were dehulled and ground before mixing in the diets.

Five protein concentrates were assayed. This involved a total of twenty-five diets, the basal diet and four levels of inclusion of the five protein concentrates and synthetic methionine. The protein concentrates and synthetic L-methionine were added to the basal diet to provide five levels of total methionine as shown in Table 2 . These supplements were added to replace the maize starch in the diets. The chemical composition of the protein concentrates is shown in Table 3.

\section{Chemical analysis}

$\mathrm{DM}$ and organic matter of food and faeces were determined after drying in a forced-air oven at $95^{\circ}$ for $24 \mathrm{~h}$ and ashing for $6 \mathrm{~h}$ at $550^{\circ}$ respectively. Total nitrogen in feed, faeces and urine was determined by the Kjeldahl method. Amino acids in the feeds were determined using ion-exchange chromatography (TSM Amino Acid AutoAnalyzer; Technicon Equipment Ltd, Sydney). Samples were hydrolysed in $6 \mathrm{M}-\mathrm{HCl}$ for $24 \mathrm{~h}$ at $110^{\circ}$.

\section{Statistical analysis}

Previous work of this type has used slope-ratio assay analysis but it was considered to be inappropriate in this case. A major requirement of slope-ratio assay analysis is that the lines fitted to the 'reference' and 'treatment' have a common intercept at the basal level and, in general, this was not the case. As methionine intake varied within a diet, linear regressions were fitted with methionine intake as the independent variable. The utilization was measured by the ratio of the two regression coefficients and the standard deviation of the ratio calculated in the usual way (Kendall \& Stuart, 1977). The data from the basal diet were included only in the synthetic methionine regression as it is not valid to include the same data in the estimate of two parameters that are to be compared.

The data in Table 4 were subjected to analysis of variance, and least significant differences $(P<0.05)$ were used to compare means statistically (Steel \& Torrie, 1960). 
Table 2. Methionine contents $(\mathrm{g} / \mathrm{kg})$ of diets

\begin{tabular}{llccccc}
\hline & \multicolumn{5}{c}{ Level of inclusion } \\
\cline { 2 - 6 } & Methionine source & 1 & 2 & 3 & 4 & 5 \\
\hline Synthetic methionine & 1.50 & 1.68 & 1.87 & 2.00 & 2.19 \\
& Meat meal A & - & 1.77 & 1.91 & 2.06 & 2.20 \\
Meat meal B & - & 1.70 & 1.89 & 2.06 & 2.21 \\
& Soya-bean meal & - & 1.70 & 1.86 & $2 \cdot 10$ & 2.24 \\
& Cotton-seed meal & - & 1.89 & 2.10 & 2.29 & 2.48 \\
& Dried skim milk & - & 1.78 & 1.93 & 2.12 & 2.26 \\
\hline
\end{tabular}

Table 3. Composition $(\mathrm{g} / \mathrm{kg})$ of dietary ingredients

\begin{tabular}{|c|c|c|c|c|c|c|c|}
\hline & Wheat & Lupins* & $\begin{array}{c}\text { Meat } \\
\text { meal } \\
\text { A }\end{array}$ & $\begin{array}{c}\text { Meat } \\
\text { meal } \\
\text { B }\end{array}$ & $\begin{array}{l}\text { Soya- } \\
\text { bean } \\
\text { meal }\end{array}$ & $\begin{array}{l}\text { Cotton- } \\
\text { seed } \\
\text { meal }\end{array}$ & $\begin{array}{l}\text { Dried } \\
\text { skim } \\
\text { milk }\end{array}$ \\
\hline $\begin{array}{l}\text { Crude protein } \\
(\text { nitrogen } \times 6.25)\end{array}$ & 124 & 341 & 489 & 474 & 446 & 400 & 354 \\
\hline Threonine & 3.4 & 10.9 & $20 \cdot 0$ & $19 \cdot 5$ & $19 \cdot 0$ & $14 \cdot 0$ & 16.0 \\
\hline Valine & $6 \cdot 3$ & 11.9 & $24 \cdot 0$ & $24 \cdot 0$ & 25.0 & $18 \cdot 0$ & $19 \cdot 0$ \\
\hline Methionine & $1 \cdot 2$ & $1 \cdot 8$ & $6 \cdot 7$ & 6.0 & $5 \cdot 6$ & $4 \cdot 0$ & $7 \cdot 5$ \\
\hline Cystine & $1 \cdot 2$ & $5 \cdot 8$ & $4 \cdot 5$ & 4.4 & $6 \cdot 5$ & $8 \cdot 0$ & 3.0 \\
\hline Isoleucine & $4 \cdot 5$ & $12 \cdot 6$ & $16 \cdot 0$ & $16 \cdot 0$ & $24 \cdot 0$ & $14 \cdot 0$ & 19.0 \\
\hline Leucine & $8 \cdot 6$ & $22 \cdot 2$ & $32 \cdot 0$ & $32 \cdot 0$ & 36.0 & $24 \cdot 0$ & 32.0 \\
\hline Phenylalanine & $5 \cdot 8$ & $12 \cdot 2$ & $19 \cdot 0$ & $19 \cdot 0$ & $25 \cdot 0$ & $19 \cdot 0$ & $15 \cdot 0$ \\
\hline Lysine & $3 \cdot 8$ & $21 \cdot 8$ & $28 \cdot 0$ & $28 \cdot 0$ & $31 \cdot 0$ & $19 \cdot 0$ & $25 \cdot 0$ \\
\hline Arginine & 6.2 & $34 \cdot 1$ & $39 \cdot 0$ & $40 \cdot 0$ & $38 \cdot 0$ & $47 \cdot 0$ & $12 \cdot 0$ \\
\hline
\end{tabular}

* Lupinus augustifolius.

RESULTS

There was a linear response in the performance of pigs to the addition to their diets of methionine from all five protein concentrates and synthetic methionine (Table 4). The weight gain of pigs given the basal diet containing $1.5 \mathrm{~g}$ methionine $/ \mathrm{kg}$ was only $61 \mathrm{~g} / \mathrm{d}$. These pigs had rough hair coats and appeared pot bellied. The average weight gain of the pigs given the diets containing $2 \cdot 2-2 \cdot 5 \mathrm{~g}$ methionine $/ \mathrm{kg}$ was $248 \mathrm{~g} / \mathrm{d}$. The feed conversion efficiency and $\mathrm{N}$ retention were also improved by supplementation of the diets with methionine.

The utilization of methionine for $\mathrm{N}$ retention appeared to be less than that for feed conversion efficiency or weight gain (Table 5). For $\mathrm{N}$ retention, the utilization of methionine from cotton-seed meal was calculated to be less than that of free methionine. For the other protein concentrates the utilization of methionine for $\mathrm{N}$ retention was not significantly different from that of free methionine, but for one of the meat meals the utilization showed a trend to poorer utilization. For feed conversion efficiency and weight gain the utilization of all protein concentrates was statistically similar to that of synthetic methionine but there appeared to be a poorer utilization of the methionine from cotton-seed meal. There was only one significant difference between the five protein concentrates in the utilization of methionine for the three measured indices, and that was the poorer utilization of methionine from cotton-seed meal for $\mathrm{N}$ retention when compared with soya-bean meal. 
Table 4. Weight gain $(g / d)$, food conversion efficiency and nitrogen retention $(g / d)$ of pigs given diets containing five protein concentrates at five levels of inclusion of methionine as shown in Tables 1 and 2

\begin{tabular}{|c|c|c|c|c|c|c|c|}
\hline \multirow[b]{2}{*}{$\begin{array}{c}\text { Level } \\
\text { of } \\
\text { inclusion }\end{array}$} & \multicolumn{7}{|c|}{ Methionine source } \\
\hline & $\begin{array}{l}\text { Synthetic } \\
\text { methionine }\end{array}$ & $\begin{array}{c}\text { Meat } \\
\text { meal } \\
\text { A }\end{array}$ & $\begin{array}{c}\text { Meat } \\
\text { meal } \\
B\end{array}$ & $\begin{array}{l}\text { Soya- } \\
\text { bean } \\
\text { meal }\end{array}$ & $\begin{array}{l}\text { Cotton- } \\
\text { seed } \\
\text { meal }\end{array}$ & $\begin{array}{l}\text { Dried } \\
\text { skim } \\
\text { milk }\end{array}$ & Mean \\
\hline \multicolumn{8}{|c|}{$\mathrm{Wt}$ gain $(\mathrm{g} / \mathrm{d})$} \\
\hline 1 & 61 & - & - & - & - & - & 61 \\
\hline 2 & 93 & 74 & 83 & 71 & 102 & 112 & 89 \\
\hline 3 & 175 & 133 & 154 & 141 & 139 & 139 & 147 \\
\hline 4 & 177 & 170 & 169 & 214 & 249 & 186 & 194 \\
\hline 5 & 268 & 198 & 240 & 221 & 292 & 272 & 249 \\
\hline Mean & 155 & 127 & 141 & 142 & 169 & 154 & - \\
\hline \multicolumn{8}{|c|}{$\begin{array}{c}9 \cdot 1 \\
\text { Food conversion efficiency }\end{array}$} \\
\hline 1 & $2 \cdot 56$ & - & - & - & - & $\ldots$ & $2 \cdot 56$ \\
\hline 2 & $2 \cdot 07$ & $2 \cdot 44$ & $2 \cdot 38$ & $2 \cdot 62$ & 1.87 & $2 \cdot 27$ & $2 \cdot 28$ \\
\hline 3 & $1 \cdot 84$ & $1 \cdot 87$ & 1.74 & 1.79 & 1.71 & $1 \cdot 77$ & 1.79 \\
\hline 4 & 1.61 & 1.71 & 1.65 & 1.55 & 1.45 & $1 \cdot 61$ & 1.60 \\
\hline 5 & 1.47 & 1.46 & 1.56 & $1 \cdot 34$ & 1.46 & $1 \cdot 40$ & 1.45 \\
\hline Mean & $1 \cdot 91$ & $2 \cdot 01$ & 1.98 & 1.97 & 1.81 & 1.92 & - \\
\hline \multicolumn{8}{|c|}{0.090} \\
\hline \multicolumn{8}{|c|}{$\mathrm{N}$ retention $(\mathrm{g} / \mathrm{d})$} \\
\hline 1 & $2 \cdot 80$ & - & - & - & 一 & 一 & $2 \cdot 80$ \\
\hline 2 & 3.05 & $2 \cdot 98$ & 3.41 & 3.81 & $4 \cdot 69$ & $4 \cdot 31$ & $3 \cdot 71$ \\
\hline 3 & $7 \cdot 02$ & $6 \cdot 33$ & 6.46 & 6.48 & $7 \cdot 01$ & $4 \cdot 86$ & $6 \cdot 36$ \\
\hline 4 & $5 \cdot 66$ & $6 \cdot 04$ & $5 \cdot 66$ & $8 \cdot 51$ & $9 \cdot 45$ & $8 \cdot 08$ & $7 \cdot 23$ \\
\hline 5 & $10 \cdot 63$ & $7 \cdot 77$ & $9 \cdot 15$ & $8 \cdot 32$ & $11 \cdot 46$ & $9 \cdot 28$ & $9 \cdot 44$ \\
\hline $\begin{array}{c}\text { Mean } \\
\text { SEM }\end{array}$ & $5 \cdot 83$ & $5 \cdot 18$ & $\begin{array}{c}5.50 \\
1.85\end{array}$ & 5.98 & $7 \cdot 08$ & 5.87 & - \\
\hline
\end{tabular}

Table 5. Utilization of methionine (relative to free methionine) in five protein concentrates using weight gain, food conversion efficiency and nitrogen retention as the criteria of response

(Mean values and their standard deviations)

\begin{tabular}{|c|c|c|c|c|c|c|}
\hline \multirow{2}{*}{$\begin{array}{l}\text { Methionine } \\
\text { source }\end{array}$} & \multicolumn{2}{|c|}{ Weight gain } & \multicolumn{2}{|c|}{$\begin{array}{l}\text { Feed conversion } \\
\text { efficiency }\end{array}$} & \multicolumn{2}{|c|}{$\mathrm{N}$ retention } \\
\hline & Mean & $\mathrm{SD}$ & Mean & $\mathrm{SD}$ & Mean & SD \\
\hline Meat meal A & 0.89 & 0.089 & 0.94 & 0.520 & 0.75 & $0 \cdot 158$ \\
\hline Meat meal B & 0.97 & $0 \cdot 094$ & $1 \cdot 01$ & 0.394 & 0.89 & $0 \cdot 182$ \\
\hline Soya-bean meal & $1 \cdot 02$ & $0 \cdot 105$ & $1 \cdot 07$ & 0.396 & $1 \cdot 04$ & 0.202 \\
\hline Cotton-seed meal & 0.87 & 0.064 & 0.63 & 0.190 & $0 \cdot 70$ & $0 \cdot 101$ \\
\hline Dried skim milk & 1.04 & $0 \cdot 102$ & 0.97 & 0.483 & 0.84 & $0 \cdot 149$ \\
\hline
\end{tabular}




\section{DISCUSSION}

In general, there was a linear response to methionine supplementation of the diet to the highest level of methionine offered in the present experiment from 1.5 to $2.2-2.5 \mathrm{~g}$ methionine $/ \mathrm{kg}$ diet. This response to the methionine supplement would be expected as the methionine requirement for $5-10-\mathrm{kg}$ pigs has been reported as $2.8 \mathrm{~g} / \mathrm{kg}$ diet by the (US) National Research Council (1979) and $3.0 \mathrm{~g} / \mathrm{kg}$ diet by the Agricultural Research Council (1981). A lower estimate was made recently in this laboratory where it was reported that $2.5 \mathrm{~g}$ methionine $/ \mathrm{kg}$ diet was sufficient for the maximum performance of pigs from $5 \mathrm{~kg}$ live weight (Leibholz, 1984). The cystine content of the diet was $3.0 \mathrm{~g} / \mathrm{kg}$, which was above the requirement of the pigs and therefore need not be considered in this discussion.

The protein content of the diet increased from a basal level of $181 \mathrm{~g} / \mathrm{kg}$ diet to $240 \mathrm{~g} / \mathrm{kg}$ diet. The basal diet contained less crude protein $(\mathrm{N} \times 6.25)$ than the published requirement of pigs of $5 \mathrm{~kg}$ live weight $(200 \mathrm{~g} / \mathrm{kg}$; (US) National Research Council, 1979). However, the (US) National Research Council (1979) requirements for all essential amino acids were met in all diets. The response to methionine supplementation would tend to confirm that methionine was the first limiting amino acid. It has been assumed that all the methionine from the synthetic methionine supplement was available, and this was used as the reference slope for the assay of methionine utilization.

Several estimates of amino acid availability from protein concentrates have been performed with older pigs (Batterham et al. 1979). As the concentration of amino acids required in the diet is greater for younger and smaller pigs, any variation in protein quality might be expected to be more critical. Batterham et al. (1979) gave a basal diet containing $4.4 \mathrm{~g}$ lysine $/ \mathrm{kg}$ to growing pigs, which is $63 \%$ of the requirement for pigs of this age ((US) National Research Council, 1979). The addition of $3 \mathrm{~g}$ lysine $/ \mathrm{kg}$ increased the mean weight gains from 384 to $610 \mathrm{~g} / \mathrm{d}$ (or a $60 \%$ increase) when the diet contained $100 \%$ of the lysine required by growing pigs ((US) National Research Council, 1979). However, the Agricultural Research Council (1981) estimated requirements for lysine by growing pigs to be $40 \%$ higher than those of the (US) National Research Council (1979). There are only small differences in the estimated requirements for methionine by pigs between these two publications. In the present experiment, the basal diet contained about $50 \%$ of the methionine requirement of young pigs (Agricultural Research Council, 1981) and this was increased by supplementation to about $75 \%$ of the methionine requirement (Agricultural Research Council, 1981). The response to this was an increase in mean weight gain from 61 to $292 \mathrm{~g} / \mathrm{d}$ or a fourfold increase. There are three possible explanations for this large response in weight gain. Firstly, young pigs may be more sensitive to amino acid deficiency than older pigs. This is the most likely explanation as Braude \& Esnaola (1973) found that increasing the methionine plus cystine content of the diets of growing pigs, from 2.7 to $4.7 \mathrm{~g} / \mathrm{kg}$ diet or from $50-90 \%$ of the requirement (Agricultural Research Council, 1981), only increased weight gains from 758 to $834 \mathrm{~g} / \mathrm{d}$. Secondly, it is possible that a methionine deficiency in the diet of pigs results in a greater depression of growth than a lysine deficiency. Thirdly, the pigs of both Braude \& Esnaola (1973) and Batterham et al. (1979) were given a restricted feed intake while the pigs in the present experiment were fed ad lib. The latter two possibilities are unlikely to offer a major explanation of the results as the growth rates, and hence feed intakes, were similar for the supplemented and unsupplemented pigs in the two experiments reported with growing pigs. In all the experiments mentioned, the authors have assumed that none of the other essential amino acids were limiting the performance of pigs, and that the diets had been calculated to meet these requirements.

The availability of lysine from protein concentrates can be reduced by severe heating and, consequently, chemical techniques for estimating lysine availability have been developed 
(Carpenter, 1960). Batterham et al. (1978) suggested that it is probable that when the availability of lysine is reduced in a protein concentrate the availability of the other amino acids will also be reduced, but this view was not shared by Taverner $e t$ al. (1981).

Batterham et al. (1979), using a slope-ratio assay with growing pigs, found that the utilization of lysine compared with free lysine for weight gain in growing pigs was 0.66 and 0.62 for meat meal and cotton-seed meal respectively, while the values for carcass gain were 0.50 and 0.39 respectively. These compare with values of $0.89-0.97$ and 0.87 for the utilization of methionine in meat meal and cotton-seed meal for weight gains in younger pigs in the present experiment. Observations with chickens showed that utilization of methionine for weight gain in meat meals varied from 0.36 to 0.68 compared with free methionine (Gutteridge \& Lewis, 1964; Miller et al. 1965), while that of cotton-seed and soya-bean meal was 1.00 (Nwokolo et al. 1976). There is a large range in the quality of meat meals and meat-and-bone meals and, until further evidence is obtained with both pigs and chickens, it cannot be assumed that the utilization of methionine from various protein sources is different for the two species.

The estimates of utilization of methionine from the present experiment are similar to the true digestibility of methionine to the ileum of these protein concentrates measured in an earlier experiment but are higher than the values for the apparent digestibility (Leibholz, 1985). The apparent digestibility of methionine from meat-meal diets to the ileum was shown to be 0.75 (Leibholz, 1985) while the retention of the apparently absorbed methionine was calculated as 0.98 . This compares with values of 0.75 and 0.89 in the present experiment. The comparison for soya-bean meal is that the apparent digestibility of methionine in the diet was 0.78 while all of the dietary methionine was utilized for $\mathrm{N}$ retention. For milk diets, the digestibility of methionine was 0.86 while the utilization of dietary methionine for $\mathbf{N}$ retention was 0.84 . However, there was better agreement between the true digestibility of methionine to the ileum and the utilization measured in the present experiment.

Alimon \& Farrell (1980) and Wilson \& Leibholz (1981) reported that for most protein concentrates the apparent digestibility of methionine to the ileum was greater than the apparent digestibility of lysine, which would agree with the better utilization of methionine from five protein sources reported here compared with that reported for the utilization of lysine by Batterham et al. (1979).

It may be concluded that the digestibility of methionine to the ileum was similar to the utilization of methionine from different sources of protein for weight gain in young pigs. Similar conclusions were reached by Achinewhu \& Hewitt (1979) in their studies with rats and chicks. As there were only small differences in these values between protein concentrates, it appears reasonable to use digestible dietary methionine to estimate the methionine requirements and utilization for weight gain by young pigs.

This study was made possible by the support of the Australian Pig Industry Research Committee. The authors are indebted to $\mathrm{Mr} \mathrm{R}$. Wheeler for technical assistance, $\mathrm{Mr} \mathrm{N}$. Peck for preparation of the lupins and Pfizer Agricare Pty Ltd for the vitamins.

\section{REFERENCES}

Achinewhu, S. C. \& Hewitt, D. (1979). British Journal of Nutrition 41, 559-571.

Agricultural Research Council (1981). The Nutrient Requirements of Pigs. Slough: Commonwealth Agricultural Bureaux.

Alimon, R. \& Farrell, D. J. (1980). Australian Journal of Agricultural Research 31, 627-635.

Balugen, O. O. \& Fetuga, B. L. A., (1981). Animal Production 33, 305-312.

Batterham, E. S., Murison, R. D. \& Lewis, C. E. (1978). British Journal of Nutrition 40, 23-28.

Batterham, E. S., Murison, R. D. \& Lewis, C. E. (1979). British Journal of Nutrition 41, 383-391.

Braude, R. \& Esnaola, M. A. (1973). British Journal of Nutrition 30, 437-445. 
Carpenter, K. J. (1960). Biochemical Journal 77, 604-610.

Gutteridge D. G. A. \& Lewis, D. (1964). British Poultry Science 5, 193-200.

Kendall, M. \& Stuart, A. (1977). The Advanced Theory of Statistics, vol. 1. New York: Charles Griffin \& Co.

Kroening, G. H., Pond, W. G. \& Loosli, J. K. (1965). Journal of Animal Science 24, 519-525.

Leibholz, J. (1984). Animal Production 39, 125-130.

Leibholz, J. (1985). British Journal of Nutrition 53, 137-147.

Miller, E. L., Carpenter, K. J., Morgan, C. B. \& Boyne, A. W. (1965). British Journal of Nutrition 19, $249-267$.

National Research Council (1979). Nutrient Requirements of Domestic Animals, No. 2 Nutrient Requirements of Swine, 8 th ed. Washington DC: National Academy of Sciences.

Nwokolo, E. N., Bragg, D. B. \& Kitts, W. D. (1976). Poultry Science 55, 2300-2304.

Steel, R. G. D. \& Torrie, J. H. (1960). Principles of Statistics, New York: McGraw-Hill Book Co.

Taverner, M. R., Hume, I. D. \& Farrell, D. J. (1981). British Journal of Nutrition 46, 159-171.

Wilson, R. H. \& Leibholz, J. (1981). British Journal of Nutrition 45, 347-357. 